\title{
APOPTOTIC CELL DEATH IN THE PORCINE ENDOMETRIUM DURING THE OESTROUS CYCLE
}

\author{
Barbara WĄSOWSKA $^{1 *}$, Beata LUDKIEWICZ ${ }^{2}$, Stanisława STEFAŃCZYK-KRZYMOWSKA ${ }^{1}$, \\ W. GRZEGORZEWSKI ${ }^{1}$ and Janina SKIPOR ${ }^{1}$ \\ ${ }^{1}$ Division of Reproductive Endocrinology and Pathophysiology, Institute of Animal \\ Reproduction and Food Research, Polish Academy of Sciences, Tuwima 10, \\ 10-747 Olsztyn 5, Box 55, Poland; ${ }^{2}$ Department of Anatomy and Neurobiology, \\ Medical Academy, Gdańsk, Poland
}

(Received May 17, 2000; accepted October 30, 2000)

\begin{abstract}
It has been reported that apoptosis plays an essential role in controlling the physiological cell kinetics in the human and rodent endometrium but this type of death has never been studied in the porcine endometrium. The aim of this study was to investigate the apoptotic cell death in the porcine endometrium during the middle (Days 9-11) and late (Day 13) luteal phase, during the luteolysis (Day 15) and early follicular phase (Days 17-19) of the oestrous cycle. Apoptotic cells were identified by in situ DNA 3'-end labelling method. It was revealed that the greatest number of apoptotic cells in the luminal and glandular epithelium was found on Days 17-19 and on Day 15 of the oestrous cycle, respectively. In the stroma, the greatest number of these cells was found on Days 9-11. Our data have shown that in the porcine endometrium, both epithelial and stromal cells undergo apoptosis and that the number of apoptotic cells varies depending on the phase of the oestrous cycle.
\end{abstract}

Key words: Apoptotic cells, porcine endometrium, TUNEL method

It has been reported that apoptosis plays an essential role in controlling the physiological cell kinetics in the female reproductive organs and tissues, such as the endometrium (Hopwood and Levison, 1976; Rotello et al., 1989; Gompel et al., 1994), ovarian follicles (Tilly et al., 1991) and regressing decidua (Gu et al., 1994).

Cells undergoing apoptosis display characteristic morphological and bi ochemical features. These features include chromatin aggregation, nuclear and c ytoplasmic condensation and partition of cytoplasm and nucleus into me mbranebound vesicles (apoptotic bodies). The biochemical hallmark of apoptosis is a de gradation of the genomic DNA. Cleavage of the DNA fragments (mono- and olig onucleosomes) as well as single strand breaks can be detected by enzymatic labe 1ling of the free 3'-OH termini with modified nucleotides (biotin- dUTP). Suitable labelling enzymes include DNA polymerase (nick translation) and terminal deox y-

*E-mail: bwasow@pan.olsztyn.pl; Fax: +48 (89) 524-0347 
nucleotidyl transferase (end labelling). The end-labelling method has also been termed TUNEL (TdT-mediated X-dUTP nick end labelling).

It has been found that atrophy of the uterus involves cell loss as well as diminution in the cell size in these organs (Kerr and Searle, 1973; Sandow et al., 1979; Nawaz et al., 1987; Rotello et al., 1989). This suggests that steroids secreted from the ovary play an important role in the maintenance of cells in their target organs. In fact, several investigations have shown that oestrogens and pr ogesterone prevent the cell loss of the uterine epithelium (Martin et al., 1976; Sandow et al., 1979; Nawaz et al., 1987; Terada et al., 1989). Thus, the preve ntion of the cell loss is one of the important actions of the ovarian steroids. Cell death after the depletion of steroids in their target organs occurs as apoptosis, a scattered cell death (Kerr and Searle, 1973; Sandow et al., 1979; Wyllie et al., 1980; Terada et al., 1985). Accordingly, the percentage of the apoptotic cells to the total cells has been used for the quantitative evaluation of the cell death $\mathrm{d}$ egree (Martin et al., 1976; Nawaz et al., 1987; Rotello et al., 1989).

Apoptotic cell death has been widely recognized in human and rodent e ndometrium; however, to our knowledge, this process has never been studied in the porcine endometrium in different phases of the oestrous cycle. In the present study, we examined changes in DNA fragmentation and in the number of apo ptotic cells in the porcine endometrium during the middle and late luteal phase, luteolysis and early follicular phase of the oestrous cycle. The apoptotic cells were identified by in situ DNA 3'-end labelling method.

\section{Materials and methods}

\section{Animals}

The study was performed in accordance with principles for the care and use of research animals. Crossbred gilts of the same weight (about $110 \mathrm{~kg}$ ) and after two recorded cycles, being in the middle (Days 9-11, n =4) and late (Day 13, n =3) luteal phase, luteolysis period (Day 15, $\mathrm{n}=3$ ) and follicular phase (Days 17-19, $n=3$ ) of the oestrous cycle were used for the study. The gilts were pretreated with atropine $(0.05 \mathrm{mg} / \mathrm{kg}$ of body mass, Biowet, Poland $)$ and propionylpromazine $(0.5 \mathrm{ml} / \mathrm{kg}$ of body mass, Combelen, Biowet, Poland $)$. General anaesthesia was induced with pentobarbitone sodium $(12 \mathrm{mg} / \mathrm{kg}$, i.v., Vetbutal, Biowet, Poland) and maintained with the supplementary administration of the anaesthetic, according to symptoms observed. The reproductive tract was exposed via a mid-ventral laparotomy under aseptic conditions. Small pieces of the endometrium were frozen in liquid nitrogen and stored in $-70{ }^{\circ} \mathrm{C}$. 


\section{Blood sample collection and determination of hormone concentration}

A silastic catheter (i. d. $1.2 \mathrm{~mm}$, o. d. $1.4 \mathrm{~mm}$ ) was inserted into the jug ular vein according to the method described by Kotwica et al. (1978). Blood samples (approximately $4 \mathrm{ml}$ ) from the jugular vein were collected for 2 days before surgery (laparotomy) four times a day (at 9 and $11 \mathrm{a} . \mathrm{m}$. and 1 and $3 \mathrm{p} . \mathrm{m}$.) and twice hourly during laparotomy.

Blood samples from the jugular vein were assayed for progesterone and oestradiol-17 $\beta$ by radioimmunoassay (RIA) to determine the hormonal status and to verify the day of the oestrous cycle. All antibodies were obtained from the Animal Physiology Institute, University of Warmia and Mazury, Olsztyn. The specificity of antibodies for progesterone has been reported by StefańczykKrzymowska et al. (1994). Progesterone was determined using the procedure d escribed in detail previously ( Stefańczyk-Krzymowska et al., 1998). The sensiti vity of the progesterone assay defined as $93 \%$ of total binding was $0.4 \mathrm{ng}$ per tube. The intra- and interassay coefficients of variations for these assays were $3.5 \%$ and $3.1 \%$, respectively. Antibodies for oestradiol-17 $\beta$ have been described by Dusza et al. (1996). Oestradiol-17 $\beta$ was determined by the method of Hotchkiss et al. (1971). The sensitivity of the oestradiol-17 $\beta$ assay was $95 \%$ of total binding and amounted to $2 \mathrm{pg}$ per tube. The intra- and interassay coefficients of vari ations were $4 \%$ and $5.8 \%$, respectively.

\section{In situ labelling of nuclear DNA fragmentation}

Eight $\mu \mathrm{m}$ thick frozen sections were mounted on slides coated with $2 \%$ aminopropyltriethoxysilane (Sigma) and fixed in 4\% paraformaldehyde in $0.1 \mathrm{M}$ phosphate buffer ( $\mathrm{pH} 7.4$ ) for $25 \mathrm{~min}$. Apoptotic activity was assessed by the te rminal deoxynucleotidyl transferase-mediated deoxyuridine triphosphate nick end labelling (TUNEL) method. The nuclei in the tissues studied were stripped of pr oteins by incubation of the sections with proteinase K ( $25 \mu \mathrm{g} / \mathrm{ml}$, Sigma) for $15 \mathrm{~min}$. Endogenous peroxidase was inactivated by covering the sections with $3 \% \mathrm{H}_{2} \mathrm{O}_{2}$ for $10 \mathrm{~min}$. The sections were rinsed with TdT buffer $(30 \mathrm{mM}$ Trisma base, $140 \mathrm{mM}$ sodium cacodylate $\mathrm{pH} 7.2,1 \mathrm{mM}$ cobalt chloride) and then incubated in TdT buffer containing terminal deoxyribonucleotidyl transferase $(0.05 \mathrm{U} / \mu \mathrm{l}$ TdT buffer; Boehringer Mannheim $)$ and biotin-16-dUTP $(0.01 \mathrm{nmol} / \mu 1$ TdT buffer; Boehringer Mannheim) in humid atmosphere at $37{ }^{\circ} \mathrm{C}$ for $60 \mathrm{~min}$. The reaction was terminated by washing the slides in $300 \mathrm{mM} \mathrm{NaCl}, 30 \mathrm{mM}$ sodium citrate for $15 \mathrm{~min}$ and blocked with $2 \%$ bovine serum albumin $(10 \mathrm{~min})$. The sections were then inc ubated with avidin-biotin-peroxidase complex (ABC kit, Vectastain, Vector) for $60 \mathrm{~min}$, followed by diaminobenzidine $/ \mathrm{H}_{2} \mathrm{O}_{2}$. Positive controls included treatment of the sections with DNAse.

In the luminal and glandular epithelium and stroma, apoptotic cells were counted in 160 fields (magnification: $\times 40$ ). 


\section{Statistical analysis}

The data are expressed as the mean $( \pm \mathrm{SE})$ of the number of apoptotic cells per one viewfield. The results obtained on Days 13, 15 and 17-19 of the oestrous cycle were compared with those found on Days 9-11. The data were analysed with one-way analysis of variance and differences were evaluated by Bonferroni adjusted $t$ value (GraphPad Prism, USA).

\section{Results}

Concentrations of progesterone and oestradiol-17 $\beta$ in the jugular vein presented typical hormonal profiles for particular days of the oestrous cycle. Levels of progesterone were $38.5 \pm 1.3 \mathrm{ng} / \mathrm{ml}$ on Days 9 to $11,25.4 \pm 1.3 \mathrm{ng} / \mathrm{ml}$ on Day $13,9.3 \pm 2.1 \mathrm{ng} / \mathrm{ml}$ on Day 15, and $1.2 \pm 0.4 \mathrm{ng} / \mathrm{ml}$ on Days 17 to 19 . Levels of oestradiol- $17 \beta$ were $17.5 \pm 1.2 \mathrm{pg} / \mathrm{ml}$ on Days 9 to $11,8.4 \pm 0.9 \mathrm{pg} / \mathrm{ml}$ on Day $13,4.6 \pm 0.5 \mathrm{pg} / \mathrm{ml}$ on Day 15, $19.3 \pm 1.1 \mathrm{pg} / \mathrm{ml}$ on Days 17 to 19 .

Apoptotic uterine luminal and glandular epithelial and stromal cells were found throughout all periods of the oestrous cycle studied. The number of apo ptotic cells in the luminal epithelium did not change considerably from the middle (Days 9-11) to the late (Day 13) luteal phase, but then it increased significantly during luteolysis (Day 15, $\mathrm{P}<0.001$ ) and early follicular phase (Days 17-19, $\mathrm{P}<0.001$, Fig. 1A and Fig. 2C). The number of apoptotic cells in the glandular epithelium did not differ between Days 9-11 and Day 13, however on Day 15 it increased significantly ( $\mathrm{P}<0.001$, Fig. 1B and 2B). In contrast, in the stroma the greatest number of apoptotic cells was found in the middle luteal phase (on Days 9-11, Fig. 1C and Fig. 2A). On Days 13, 15 and 17-19, the number of apoptotic cells was significantly lower than on Days 9-11 ( $\mathrm{P}<0.001)$. The apoptotic cells contained irregular nuclei with condensed chromatic clumped along the nuclear membrane (arrows, Fig. 2).

\section{Discussion}

The endometrium undergoes major histological and biochemical changes during the oestrous cycle. The uterine tissue dynamics is associated with periods characterized by declining steroid hormone concentrations, fluctuating hormone ratios, apoptosis and tissue loss. A consequence of the reduction in steroid ho rmone levels, in general, is epithelial apoptosis and tissue reorganisation ( Fesus et al., 1991; Tenniswood et al., 1992). The porcine endometrium undergoes regular cycles of remodelling under hormonal control. This tissue, composed primarily of stromal and epithelial cells, requires oestrogens and progesterone for correct functioning during particular stages of the oestrous cycle (Duenbostel and Paufler, 1983; Stroband et al., 1986; Leiser et al., 1988). The present study, for the 
first time in gilts, demonstrated that apoptotic cell death occurs in uterine luminal and glandular epithelial cells and stroma cells during the middle and late luteal and early follicular phases of the oestrous cycle, indicating that apoptosis is a physiological phenomenon in the porcine uterus. Apoptosis is a specific form of cell death that differs from necrosis by the morphological changes in the nucleus, by the formation of apoptotic bodies, and, in epithelial tissues, by heterophagy or macrophagy (Kerr et al., 1972). Cohen et al. (1992) have asserted that the fra gmentation of DNA is not strictly specific of apoptosis and may accompany other modes of cell death. However, Ben-Sasson et al. (1995) have claimed that, at the tissue level, apoptosis can be differentiated by several criteria, even when tissue is stained by using the in situ DNA 3'-end labelling method: apoptosis is an ordered process, whereas necrosis represents chaos. Therefore, in any given tissue, the pattern of in situ DNA 3'-end labelling is distinct.
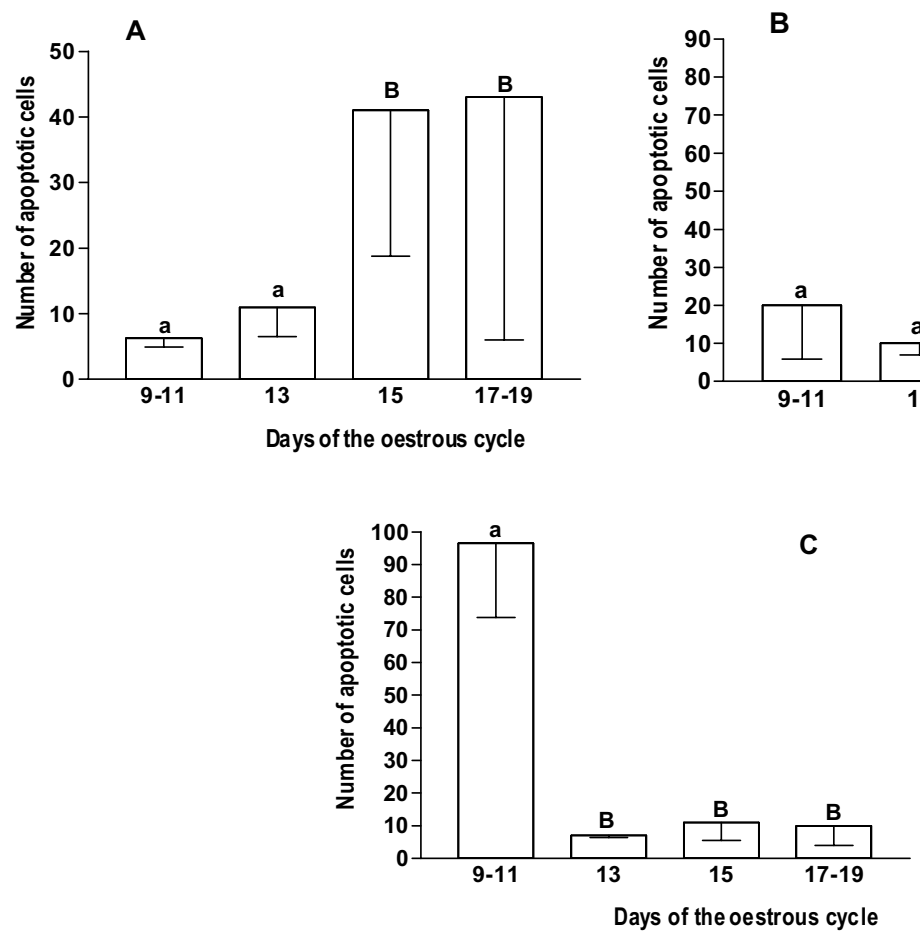

Fig. 1. Mean ( $\pm \mathrm{SE})$ number of apoptotic cells in the luminal epithelium (A), glandular epithelium (B) and stroma (C). $\mathrm{B}=\mathrm{P}<0.001$

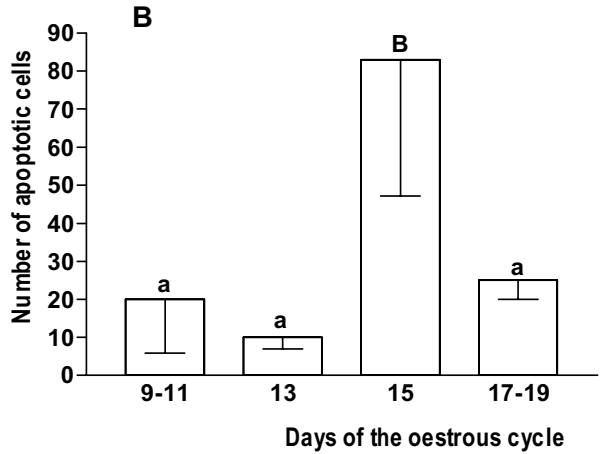



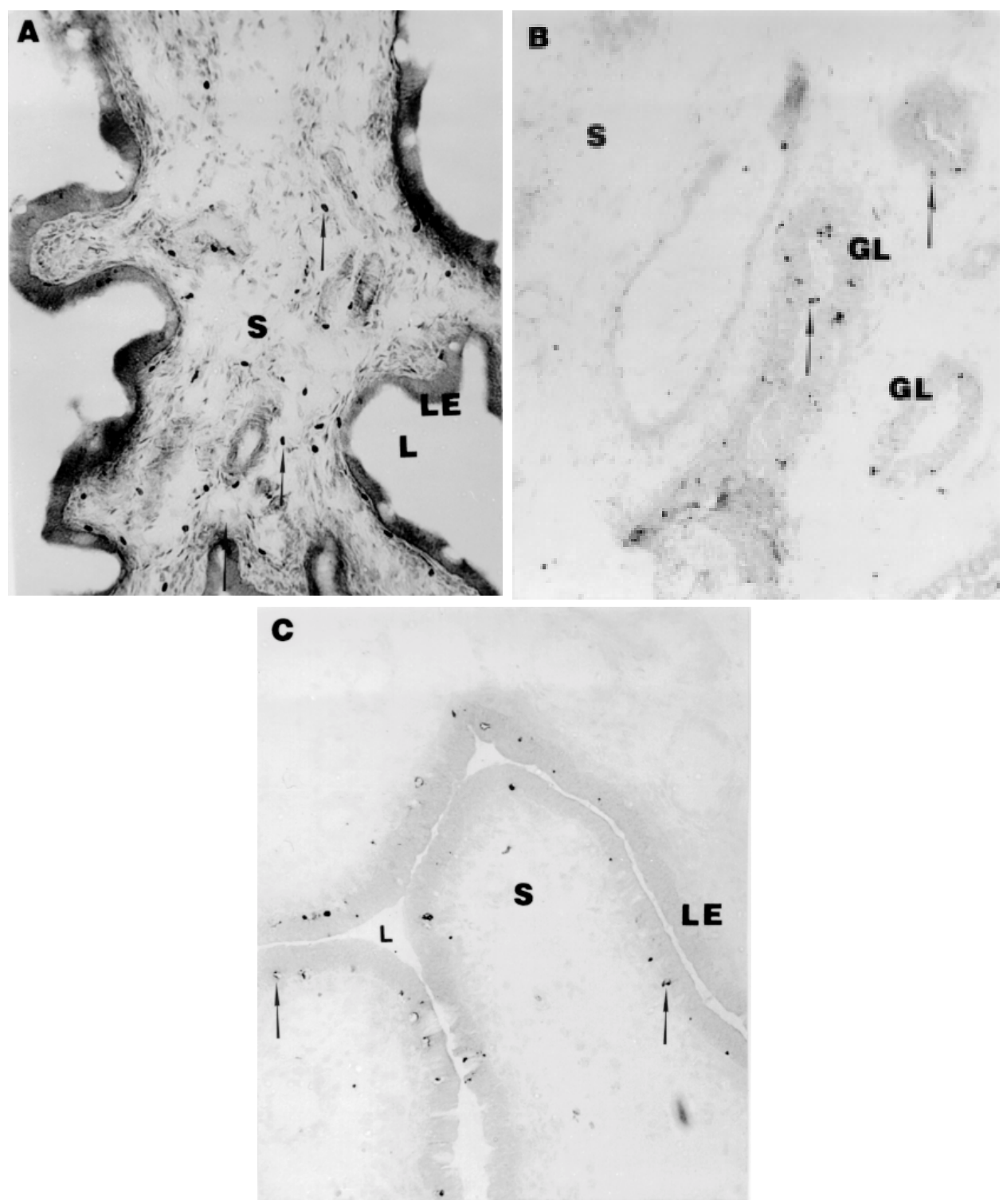

Fig. 2. Light micrographs of porcine endometrium. In situ DNA 3'-end labelling reaction in the uterus. $\mathrm{S}=$ stroma, $\mathrm{LE}=$ luminal epithelium, $\mathrm{GL}=$ glandular epithelium, $\mathrm{L}=$ lumen. Uterine stromal - A (Days 9-11, × 125), glandular epithelial - B (Day 15, × 250) and luminal epithelial $-\mathrm{C}$ (Days 17-19, $\times 125$ ) cells showing apoptosis (arrows)

Uterine epithelial cell proliferation, differentiation, and death are known to be regulated by oestrogens and progesterone. Actions of various steroids for the cell death in the uterine epithelium may differ among animal species. The present 
study demonstrated a significant increase in the number of apoptotic cells in the porcine luminal epithelium during luteolysis when the level of progesterone co nsiderably decreases and oestradiol-17 $\beta$ reaches the lowest level. Similar numbers of apoptotic cells were found in the luminal epithelium during the early follicular phase, albeit the level of oestradiol-17 $\beta$ was already high. On the other hand, in the glandular epithelium the number of apoptotic cells was prominent during $1 \mathrm{u}$ teolysis, but in the follicular phase it decreased. Sato et al. (1997) have demo nstrated that apoptotic cell death occurs in rat uterine luminal and glandular epithelial and stromal cells during the oestrous cycle. Apoptotic cells appeared in the uterine luminal epithelium at oestrus and increased in number during $\mathrm{m}$ etoestrus (Sato et al., 1997), which correlates with the reduction of oestrogen level at oestrus and metoestrus (Short, 1972; Spornitz et al., 1994). However, with r egard to uterine glandular cells, the apoptotic index was highest at oestrus but lowest at metoestrus, and there were almost no the apoptotic cells at dioestrus and prooestrus. In contrast, only a small number of apoptotic cells was found among stromal cells throughout the oestrous cycle (Sato et al., 1997). In the hamster uterus, apoptosis occurs in the luminal epithelium during oestrus. A ccording to Sandow et al. (1979), apoptosis is caused by oestrogen withdrawal and can be prevented by oestrogen treatment. In ovariectomised adult mice, pr ogesterone alone or in combination with oestrogens reduced cell death in the uterine epithelium (Terada et al., 1989). Rotello et al. (1989) have demonstrated that progesterone suppresses apoptosis, but a progesterone antagonist induces apoptosis in the rabbit uterine epithelium. Nawaz et al. (1987) reported that oe strogens did not maintain the uterine epithelial cells in pseudopregnant rabbits after castration, although progesterone did. However, these authors did not e xamine the effect of oestrogens or progesterone on the uterine epithelium in ca strated rabbits primed with oestrogens. In the human uterus, apoptosis occurs during the secretory phase of the menstrual cycle, and the late secretory, preme nstrual, and menstrual endometrium shows numerous apoptotic bodies (Hopwood and Levison, 1976). Harada et al. (1996) have failed to detect evidence for apoptosis in the human endometrial epithelium, although others reported apo ptotic epithelial cells in the secretory phase with the highest level during me nstruation (Tabibzadeh et al., 1994; Yasuda et al., 1995). It is interesting that in our study, apoptotic cells in the stroma were found in all investigated phases of the oestrous cycle, and the greatest number of these cells was found on Days 911. Several studies revealed elevated $b c l-2$ (B cell lymphoma/leukaemia-2 gene) expression with predecidualisation in the late secretory phase, which was attri buted to an increase in endometrial stroma bcl-2+ CD56+ eGLs (Koh et al., 1995). Jones et al. (1998), however, suggested that eGLs at the end of the cycle and first-trimester decidua do not undergo apoptosis.

In conclusion, the present study has revealed that porcine endometrial epithelial and glandular cells and stromal cells undergo apoptotic cell death. The 
number of apoptotic cells was different in particular phases of the oestrous cycle. These data suggest that apoptotic cell death in the epithelium may participate in the remodelling of uterine tissues, especially during luteolysis when the luteal phase turns into the follicular phase.

\section{References}

Ben-Sasson, S. A., Sherman, Y. and Gavrieli, Y. (1995): Identification of dying cells - in situ staining. In: Schwartz, L. M. and Osborne, B. A. (eds) Methods in Enzymology. Vol. 46: Cell Death. Academic Press, San Diego, pp. 29-39.

Cohen, G. M., Sun, X. M., Snowden, D., Dinsdale, D. and Skilleter, D. N. (1992): Key morphological features of apoptosis may occur in the absence of internucleosomal DNA fragmentation. Biochem. J. 286, 331-334.

Duenbostel, K. von and Paufler, S. (1983): Rasterelektronenmikroskopische Untersuchungen der Oberflachenstruktur des weiblichen Genitaltrakts vom Schwein im Stadium des Diöstrus. Dtsch. Tierärztl. Wschr. 90, 528-533.

Dusza, L., Opałka, M., Kamińska, B. and Ciereszko, R. E. (1996): The relationship between resistance of vaginal mucus and plasma hormonal parameters during periestrus in sows. Theriogenology 45, 1491-1503.

Fesus, I., Davies, P. J. A. and Piacentini, M. (1991): Apoptosis: molecular mechanisms in programmed cell death. Eur. J. Cell Biol. 56, 170-177.

Gompel, A., Sabourin, J. C., Martin, A., Yaneva, H., Audouin, J., Decroix, Y. and Poitout, P. (1994): Bcl-2 expression in normal endometrium during the menstrual cycle. Am. J. Pathol. 144, 1195-1202.

Gu, Y., Jow, G. M., Moulton, B. C., Lee, C., Sensibar, J. A., Park-Sarge, O. K., Chen, T. J. and Gibori, G. (1994): Apoptosis in decidual tissue regression and reorganization. Endocrinology 135, 1272-1279.

Harada, M., Suganuma, N., Furuhashi, M., Nagasaka, T., Nakashima, N., Kikkawa, F., Tomoda, Y. and Furui, K. (1996): Detection of apoptosis in human endometriotic tissues. Mol. Hum. Reprod. 2, 307-315.

Hopwood, D. and Levison, D. A. (1976): Atrophy and apoptosis in the cyclical human endometrium. J. Pathol. 119, 159-166.

Hotchkiss, J., Atkinson, L. E. and Knobil, E. (1971): Time course of serum estrogen and luteinizing hormone $(\mathrm{LH})$ concentration during menstrual cycle at the rhesus monkey. Endocrinol. 89, 177-184.

Jones, R. K., Searle, R. F., Stewart, J. A., Turner, S. and Bulmer, J. N. (1998): Apoptosis, bcl-2 expression, and proliferative activity in human endometrial stroma and endometrial granulated lymphocytes. Biol. Reprod. 58, 995-1002.

Kerr, J. F. R. and Searle, J. (1973): Deletion of cells by apoptosis during castration induced involution of rat prostate. Virchows Arch. (Cell Path.) 13, 87-102.

Kerr, J. F. R., Wyllie, A. H. and Currie, A. R. (1972): Apoptosis: A basic biological phenomenon with wide ranging implications in tissue kinetics. Br. J. Cancer 26, 239-257.

Koh, E. A., Illingworth, P. J., Duncan, W. C. and Critchley, H. O. (1995): Immunolocalization of bcl-2 protein in human endometrium in the menstrual cycle and simulated early pregnancy. Hum. Reprod. 10, 1557-1562.

Kotwica, J., Krzymowski, T. and Dębek, J. (1978): Cannulation of venous vessels in swine for endocrinological studies (in Polish). Med. Wet. 34, 118-120.

Leiser, R., Zimmermann, W., Sidler, X. and Christen, A. (1988): Normal-zyklische Erscheinungen im Endometrium and am Ovar des Schweines. Tierärztl. Prax. 16, 261-280. 
Martin, L., Pollard, J. W. and Fagg, B. (1976): Oestriol, oestradiol-17 $\beta$ and the proliferation and death of uterine cells. J. Endocr. 69, 103-115.

Nawaz, S., Lynch, M. P., Galand, P. and Gerschenson, L. E. (1987): Hormonal regulation of cell death in rabbit uterine epithelium. Am. J. Path. 127, 51-59.

Rotello, R. J., Hocker, M. B. and Gerschenson, L. E. (1989): Biochemical evidence for programmed cell death in rabbit uterine epithelium. Am. J. Pathol. 68, 435-443.

Sandow, B. A., West, N. B., Norman, R. L. and Brenner, R. M. (1979): Hormonal control of apoptosis in hamster uterine luminal epithelium. Am. J. Anat. 156, 15-36.

Sato, T., Fukazawa, Y., Kojima, H., Masata, E., Iguchi, T. and Ohta, Y. (1997): Apoptotic cell death during the estrous cycle in the rat uterus and vagina. Anat. Rec. 248, 76-83.

Short, R. V. (1972): Role of hormones in sex cycle. In: Reproduction in Mammals Vol. 3, Cambridge University Press, London, pp. 42-72.

Spornitz, U. M., Rinderknecht, B. P., Edelmann, B., Scheidegger, B. and Cairolli, F. (1994): Ultrastructure as a basis for dating of rat endometrium. Anat. Rec. 238, 163-176.

Stefańczyk-Krzymowska, S., Skipor, J., Grzegorzewski, W., Wąsowska, B. and Krzymowski, T. (1994): Local increase of steroid hormone concentrations in blood supplying the uterus and oviduct in anaesthetized and conscious gilts. Anim. Reprod. Sci. 37, 35-41.

Stefańczyk-Krzymowska, S., Grzegorzewski, W., Wąsowska, B., Skipor, J. and Krzymowski, T. (1998): Local increase of ovarian steroid hormone concentration in blood supplying the oviduct and uterus during early pregnancy of sows. Theriogenology 50, 1071-1080.

Stroband, H. W. J., Taverne, N., Langenfeld, K. and Barends, P. M. G. (1986): The ultrastructure of the uterine epithelium of the pig during the estrous cycle and early pregnancy. Cell Tissue Res. 246, 81-89.

Tabibzadeh, S., Kong, Q. F., Satyaswaroop, P. G., Zupi, E., Marconi, D., Romanini, C. and Kapur, S. (1994): Distinct regional and menstrual cycle dependent distribution of apoptosis in human endometrium. Potential regulatory role of T cells and TNF-alpha. Endocr. J. 2, 87-95.

Tenniswood, M. P., Guenette, R. S., Lakins, J., Moibroek, M., Wong, P. and Welsh, J. (1992): Active cell death in hormone dependent tissues. In: Frost, P., Hart, I., Kerbel, R. (eds) Cancer Metastasis Rev. Kluwer Academic Publishers, Dordrecht, The Netherlands 11, 197-220.

Terada, N., Ogasawara, Y., Yamane, T., Matsumoto, K. and Kitamura, Y. (1985): Heterogeneity in mouse seminal vesicle epithelial cells responding to androgen as evaluated by incorporation of $\left[{ }^{125} \mathrm{I}\right]$-iododeoxyuridine. Endocrinology 116, 1466-1472.

Terada, N., Yamamoto, R., Takada, T., Miyake, T., Terakawa, N., Wakimoto, H., Taniguchi, H., Li, W., Kitamura, Y. and Matsumoto, K. (1989): Inhibitory effect of progesterone on cell death of mouse uterine epithelium. J. Steroid Biochem. 33, 1091-1096.

Tilly, J. L., Kowalski, K. I., Johnson, A. L. and Hsueh, A. J. W. (1991): Involvement of apoptosis in ovarian follicular atresia and postovulatory regression. Endocrinol. 129, 2799-2801.

Wyllie, A. H., Kerr, J. F. R. and Currie, A. R. (1980): Cell death: the significance of apoptosis. Int. Rev. Cytol. 68, 251-306.

Yasuda, M., Umemura, S., Osamura, R. Y., Kenjo, T. and Tsutsumi, Y. (1995): Apoptotic cells in the human endometrium and placental villi: pitfalls in applying the TUNEL method. Arch. Histol. Cytol. 58, 185-190. 